\title{
One-Year Characterization and Reactivity of Isoprene and Its Impact on Surface Ozone Formation at A Suburban Site in Guangzhou, China
}

\author{
Yu Zou *, Xue Jiao Deng, Tao Deng ${ }^{\circledR}$, Chang Qin Yin and Fei Li \\ Institute of Tropical and Marine Meteorology, China Meteorological Administration (CMA), 510000 Guangzhou, \\ China; dxj@grmc.gov.cn (X.J.D.); tdeng@grmc.gov.cn (T.D.); yincq@grmc.gov.cn (C.Q.Y.); lifei@grmc.gov.cn (F.L.) \\ * Correspondence: yzou@grmc.gov.cn
}

Received: 22 March 2019; Accepted: 12 April 2019; Published: 15 April 2019

check for updates

\begin{abstract}
Isoprene has a potentially large effect on ozone $\left(\mathrm{O}_{3}\right)$ formation in the subtropical, highly polluted city of Guangzhou. Online measurements of isoprene in Guangzhou city are scarce; thus, isoprene levels were monitored for one year at the Guangzhou Panyu Atmospheric Composition Station (GPACS), a suburban site in Guangzhou, using an online gas chromatography-flame ionization detector (GC-FID) system to investigate the characterization and reactivity of isoprene and its effect on the $\mathrm{O}_{3}$ peak profile in different seasons. The results showed that the daily average mixing ratios of isoprene at GPACS were $0.40,2.20,1.40$, and 0.13 mixing ratio by volume (ppbv) in spring, summer, autumn, and winter, respectively. These values were considerably higher than the mixing ratios of isoprene in the numerous other subtropical and temperate cities around the world. Furthermore, isoprene ranked first with regard to $\mathrm{O}_{3}$ formation potential (OFP) and propylene-equivalent mixing ratio among 56 measured non-methane hydrocarbons (NMHCs). The ratios of isoprene to cis-2-butene, an exhaust tracer, were determined to estimate the fractions of biogenic and anthropogenic emissions. The results revealed a much greater contribution from biogenic than anthropogenic factors during the daytime in all four seasons. In addition, night-time isoprene emissions were mostly associated with vehicles in winter, and the residual isoprene that remained after photochemical loss during the daytime also persisted into the night. The high levels of isoprene in summer and autumn may cause the strong and broad peaks of the $\mathrm{O}_{3}$ profile because of its association with the most favorable meteorological conditions (e.g., high temperature and intense solar radiation) and the highest $\mathrm{OH}$ mixing ratio, which could affect human health by exposing people to a high $\mathrm{O}_{3}$ mixing ratio for prolonged periods. The lower mixing ratios of isoprene resulted in a weak and sharp peak in the $\mathrm{O}_{3}$ profile in both spring and winter. The high level of isoprene in the subtropical zone could accentuate its large impact on atmospheric oxidant capacity and air quality in Guangzhou city.
\end{abstract}

Keywords: Characterization; reactivity; isoprene; ozone formation; Guangzhou

\section{HIGHLIGHTS}

- The characterization and reactivity of isoprene at a subtropical suburban site in Guangzhou were investigated.

- Isoprene ranked first for OFP and propylene-equivalent mixing ratio during the $\mathrm{O}_{3}$ formation period.

- Daytime biogenic isoprene emissions dominated over anthropogenic isoprene emissions in all four seasons.

- Vehicular emissions contributed approximately $71.6 \%, 30.5 \%$, and $33.1 \%$ of night-time isoprene emissions in spring, summer, and autumn, respectively. 
- The high (low) levels of isoprene could shape the strong (weak) and broad (sharp) peaks in the $\mathrm{O}_{3}$ profile.

\section{Introduction}

As a consequence of rapid economic development and urbanization, high-mixing ratio ozone $\left(\mathrm{O}_{3}\right)$ events occur frequently in Guangzhou, one of the most polluted megacities in China [1-3]. The Guangzhou Panyu Atmospheric Composition Station (GPACS) defines $\mathrm{O}_{3}$ exceedance as a daily maximum eight-hour average $\mathrm{O}_{3}$ mixing ratio of greater than 80 mixing ratio by volume (ppbv) that lasts for more than four hours [4]. Guangzhou City experienced $174 \mathrm{O}_{3}$ exceedance days from 2010 to 2016 [3].

A series of strategies intended to improve air quality have been implemented in the PRD (Pearl River Delta) region. For example, the 12th Five-Year Plan (2011-2015) included a national campaign aimed at reducing $\mathrm{NO}_{x}$ and $\mathrm{SO}_{2}$ emissions by $10 \%$ and $8 \%$, respectively, based on 2010 emission levels. The joint governments of Guangdong Province and Hong Kong endorsed "The PRD Air Pollutant Emission Reduction Plan up to 2020", which specifies that by 2020, emissions of $\mathrm{SO}_{2}, \mathrm{NO}_{x}$, and volatile organic compounds (VOCs) within mainland PRD should be reduced by $20-35 \%, 20-40 \%$, and $15-25 \%$, respectively, compared with those in $2010[5,6]$. The air pollution control measures successfully reduced the mixing ratios of $\mathrm{O}_{3}$ precursors (i.e., VOCs and $\mathrm{NO}_{x}$ ) in PRD. However, $\mathrm{O}_{3}$ was not mitigated in Guangzhou as expected [7]. A primary reason for this inconsistency was the reduced $\mathrm{NO}_{-} \mathrm{O}_{3}$ titration, which was a result of the reduction in $\mathrm{NO}_{x}$ emissions. Wang et al. [8] also suggested that the regional sources and weather conditions significantly influenced and contributed to $\mathrm{O}_{3}$ levels. Another significant reason that cannot be ignored is the presence of biogenic VOCs (e.g., isoprene), as these were not the targets of the control measures. Some prior studies noted that a reduction in anthropogenic VOC emissions as an $\mathrm{O}_{3}$ reduction strategy would only lead to a slight decrease in $\mathrm{O}_{3}$ mixing ratio if biogenic VOCs were present in the atmosphere $[9,10]$.

Isoprene has drawn attention because it has both a high reactivity and high $\mathrm{O}_{3}$-formation potential and, therefore, can contribute to quick and efficient $\mathrm{O}_{3}$ formation [11]. In contrast to the anthropogenic emissions, maximum isoprene emissions are reached around midday due to the high temperature and intense solar radiation, and therefore, occur during the time of day with the most favorable photochemical conditions [12]. As opposed to most other precursors of $\mathrm{O}_{3}$, which are almost exclusively from anthropogenic sources, a significant fraction of isoprene is biogenic in origin. In terms of global isoprene emission estimations, approximately $90 \%$ of the isoprene released into the atmosphere is produced by terrestrial plants [13]. Nevertheless, isoprene has both biogenic and anthropogenic sources in urban areas [14,15]. Accordingly, a previous study in a temperate urban area reported isoprene's relatively strong anthropogenic contribution in winter [16].

Only a few measurements of the isoprene mixing ratio have been conducted in China's megacities [4,17] and most of them used off-line measurement; little long-term continuous observational data is available for isoprene, which only serves to limit our understanding of its characteristics and its effect on $\mathrm{O}_{3}$ production in Guangzhou. In addition, as Guangzhou is located in a subtropical zone with high temperatures and high light flux, it provides ideal conditions for biogenic isoprene emissions, and high isoprene levels have a large effect on $\mathrm{O}_{3}$ formation. In crafting control strategies for the key precursors of $\mathrm{O}_{3}$ in Guangzhou, the investigation of isoprene is essential.

This study aims to provide a clearer understanding of the characteristics, sources, and role of isoprene in Guangzhou based on observational data taken over the period of one year, which could specifically help with developing new $\mathrm{O}_{3}$ control measures to improve the city's air quality. In the present paper, we document general information about the sampling site and the data collection procedure (Section 2), as well as the overall characteristics of NMHCs (non-methane hydrocarbons) and their relative potential for $\mathrm{O}_{3}$ formation (Section 3.1). Biogenic and anthropogenic effects on isoprene are also presented, (Section 3.2) and finally, the effect of isoprene on the $\mathrm{O}_{3}$ peak profile is discussed (Section 3.3). 


\section{Methodology}

\subsection{Site Description}

From June 2011 to May 2012, NMHCs and $\mathrm{O}_{3}$ were measured simultaneously at the Guangzhou Panyu Atmospheric Composition Station (GPACS) operated by the Institute of Tropical and Marine Meteorology (ITMM) of China Meteorological Administration (CMA). The GPACS site $\left(23^{\circ} 00^{\prime} \mathrm{N}\right.$, $113^{\circ} 21^{\prime} \mathrm{E}, 141 \mathrm{~m}$ ) is within the boundary layer [18], which is located at the center of the PRD on the hilltop of Dazhengang, Nancun Town, Panyu District, Guangzhou, China (Figure 1). It is about $120 \mathrm{~m}$ above the city with surrounding trees and no significant industrial pollution sources nearby [3,19-21]. At the measurement site, the average temperature ranged from $14.2{ }^{\circ} \mathrm{C}$ in winter to $29.4{ }^{\circ} \mathrm{C}$ in summer, while the solar radiation ranged from $206.8 \mathrm{w} / \mathrm{m}^{2}$ in winter to $415.1 \mathrm{w} / \mathrm{m}^{2}$ in summer (Table 1). The relatively high temperature and high levels of solar radiation in this subtropical suburban site make it a good location to assess the importance of isoprene with regard to atmospheric photochemical pollution.

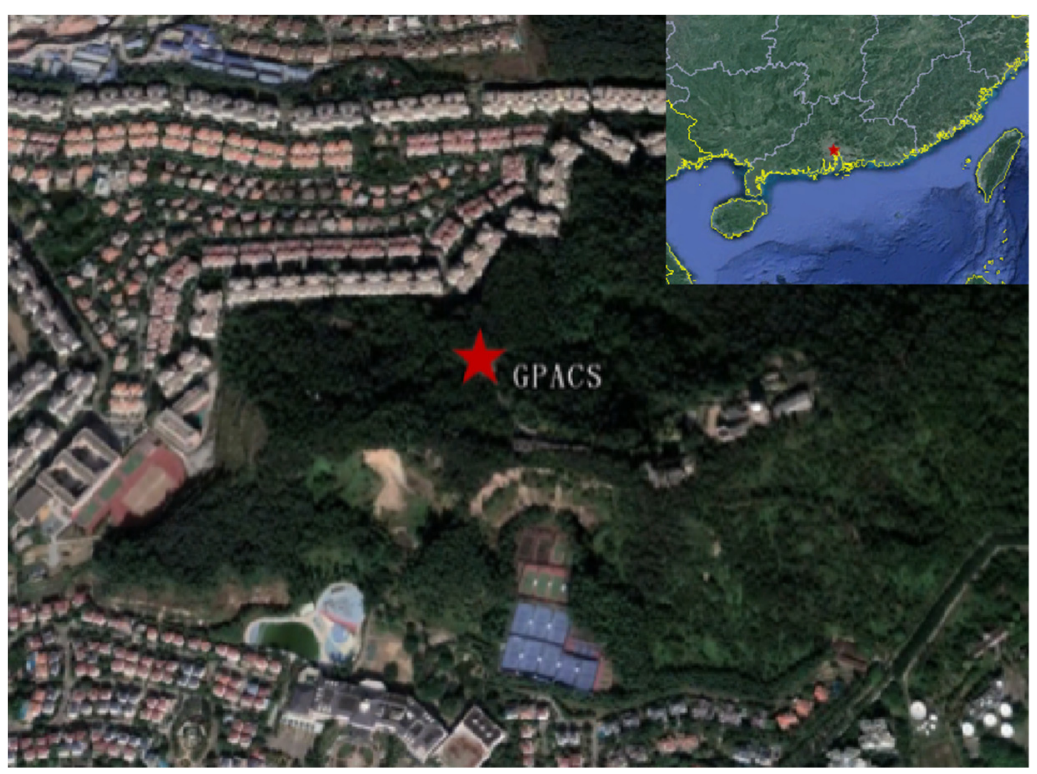

Figure 1. Observation site at GPACS (Guangzhou Panyu Atmospheric Composition Station) and its surrounding area from Google Maps.

Table 1. The temperature and solar radiation (7:00-18:00 Local Time (LT)) in each season from June 2011 to May 2012 at GPACS.

\begin{tabular}{cccccc}
\hline Season & Meteorological Element & Minimum & Maximum & Mean & Median \\
\hline Spring & Temperature $\left({ }^{\circ} \mathrm{C}\right)$ & 9.4 & 35.5 & 22.6 & 22.9 \\
(March, April, May) & Solar Radiation $\left(\mathrm{w} / \mathrm{m}^{2}\right)$ & 0.1 & 886.5 & 271.2 & 199.9 \\
\hline Summer & Temperature $\left({ }^{\circ} \mathrm{C}\right)$ & 23.9 & 37.1 & 29.4 & 28.8 \\
(June, July, August) & Solar Radiation $\left(\mathrm{w} / \mathrm{m}^{2}\right)$ & 4.1 & 952.5 & 415.1 & 381.3 \\
\hline Autumn & Temperature $\left({ }^{\circ} \mathrm{C}\right)$ & 16.2 & 35.3 & 25.2 & 25.2 \\
$\begin{array}{c}\text { (September, October, } \\
\text { November) }\end{array}$ & Solar Radiation $\left(\mathrm{w} / \mathrm{m}^{2}\right)$ & 0.3 & 901.0 & 294.4 & 238.1 \\
\hline Winter & Temperature $\left({ }^{\circ} \mathrm{C}\right)$ & 4.7 & 26.9 & 14.2 & 14.1 \\
$\left(\begin{array}{c}\text { December, January, } \\
\text { February) }\end{array}\right.$ & Solar Radiation $\left(\mathrm{w} / \mathrm{m}^{2}\right)$ & 0.1 & 693.5 & 206.8 & 135.3 \\
\hline
\end{tabular}

\subsection{Instrumentation}

Using a traditional offline sampling method, it is difficult to meet the requirements of isoprene detection due to the high atmospheric chemical reactivity of isoprene. In this study, isoprene was 
continuously monitored using the GC5000 analysis system coupled with flame ionization detectors (AMA, Germany). This system includes a low boiling point NMHC analyzer (GC5000VOC) for $\mathrm{C}_{2}-\mathrm{C}_{6}$ NMHC species and a high boiling point NMHC analyzer (GC5000BTX) for $\mathrm{C}_{6}-\mathrm{C}_{12} \mathrm{NMHC}$ species. Isoprene was measured using the low boiling point NMHC analyzer, where air samples were enriched through a two-stage trap, and then thermally desorbed when the temperature increased to $200{ }^{\circ} \mathrm{C}$, followed by separation with two-dimensional chromatography. The chromatographic columns consisted of an $\mathrm{Al}_{2} \mathrm{O}_{3} / \mathrm{Na}_{2} \mathrm{SO}_{4}$ PLOT column $(60 \mathrm{~m} \times 0.32 \mathrm{~mm}$ inner diameter $\times 5 \mu \mathrm{m}$ thickness $)$ and a CARBOWAX ${ }^{\mathrm{TM}}$ back-flushing column $(30 \mathrm{~m} \times 0.32 \mathrm{~mm}$ inner diameter $\times 0.25 \mu \mathrm{m}$ thickness). The back-flushing column was first used to remove the moisture component and high-boiling NMHC species. Then, the PLOT column was followed to separate the low-boiling NMHC species. Quality assurance (QA)/quality control (QC) of online NMHCs measurements was performed. Zero and span gas checks (using Photochemical Assessment Monitoring Stations (PAMS) calibration gases including isoprene) were conducted monthly throughout the observation period. Five-level calibration curves were used to quantify the isoprene level during online monitoring. The correlation coefficient and detection limits of isoprene were 0.998 and $0.07 \mathrm{ppbv}$ (Parts Per Billion by Volume), respectively. The outliers (about $8 \%$ ), which were identified by the VOC data validation program recommended by US EPA PAMS (United States Environmental Protection Agency Photochemical Assessment Monitoring Stations) [22], were eliminated before data processing to guarantee the validity of the data. It should be noted that missing data (from 20 January 2012 to 20 March 2012) were caused due to instrument malfunction. The instrument and QA/QC have been described in detail elsewhere [20,23]. In addition, $\mathrm{O}_{3}$ was measured with an EC9810B O $\mathrm{O}_{3}$ analyzer (Ecotech Co., Australia) based on the UV-absorption method and the Beer-Lambert law. QA/QC was performed every month, including inspection of the instruments, as well as zero, precision, and span checks. The filter was replaced once every two weeks and calibration was carried out every month. The $\mathrm{O}_{3}$ mixing ratio was recorded every five minutes in instrument. For convenience of analysis, the $\mathrm{O}_{3}$ data was processed one $\mathrm{h}$ into the study.

\subsection{Data Analysis}

\subsubsection{The Effect of NMHCs on $\mathrm{O}_{3}$ Formation}

NMHCs exhibit a wide range of reactivities, and two common and useful scales have been proposed for quick and convenient evaluation of the $\mathrm{O}_{3}$ formation potential (OFP) or the NMHCs relative reactivities. The maximum incremental reactivity (MIR) scale is used to estimate the potential of individual NMHCs to contribute to $\mathrm{O}_{3}$ formation using the mechanism reactivity. The OFP, which represents the maximum ozone mixing ratio generated by this species based on estimated MIR, was calculated by the equation below:

$$
\operatorname{OFP}(j)=\operatorname{MIR}(j) \times C(j) \times \frac{m(j)}{M}
$$

where $C(j)$ represents the actual mixing ratio by volume (ppbv) for species $j, M$ represents the molecular mass of $\mathrm{O}_{3}$, and $m(j)$ represents the relative molecular mass of species $j$ in the NMHCs. The MIR $(j)$ was estimated by selecting the specific MIR value for each of the NMHCs from published studies, which were conducted based on modeled scenarios for Los Angeles in the 1980s [11,24].

The OH-reactivity scale is a means of determining the reactivity of NMHCs with $\mathrm{OH}$ radicals using kinetic reactivity. Although the initial reactivity of $\mathrm{NMHC}$ with $\mathrm{OH}$ in the $\mathrm{OH}$-reactivity scale does not directly reflect the OFP, it indicates the potential for subsequent product formation after reaction with $\mathrm{OH}$. In order to normalize $k_{\mathrm{OH}}$ for $\mathrm{NMHCs}$, in this study, the propylene-equivalent mixing ratio was calculated using the equation below:

$$
\operatorname{Prop}-\operatorname{Equiv}(j)=C(j) \times \frac{k_{\mathrm{OH}}(j)}{k_{\mathrm{OH}}\left(C_{3} H_{6}\right)}
$$


where $j$ represents a NMHC species, $\mathrm{C}(\mathrm{j})$ represents the carbon atom mixing ratio (ppbC) of this species, and $k_{\mathrm{OH}}(j)$ and $k_{\mathrm{OH}}\left(\mathrm{C}_{3} \mathrm{H}_{6}\right)$ denote the chemical reaction rate constant in the free radical reaction of species $j$ and propylene with $\mathrm{OH} ; k_{\mathrm{OH}}(j)$ was obtained from a study by Atkinson and Aery [25].

In this study, both the MIR scale and the $\mathrm{OH}$-reactivity scale were utilized. The $\mathrm{OH}$ reaction rate constants and estimated MIR coefficients, as well as their mixing ratios, for each NMHC species, are shown in Table 2.

Table 2. The NMHCs' OH (hydroxyl radicals of non-methane hydrocarbons) reaction rate constants, estimated MIR (maximum incremental reactivity) coefficients, and their hourly mean mixing ratios at GPACS from June 2011 to May 2012.

\begin{tabular}{|c|c|c|c|}
\hline Compound & $k^{\mathrm{a}} \mathrm{OH} \times 10^{12}$ & MIR $^{b}$ & Mixing Ratio (ppbv) (Parts Per Billion by Volume) \\
\hline \multicolumn{4}{|l|}{ Alkanes } \\
\hline Ethane & 0.27 & 0.25 & 3.66 \\
\hline Propane & 1.15 & 0.46 & 4.34 \\
\hline i-Butane & 2.34 & 1.18 & 2.67 \\
\hline n-Butane & 2.54 & 1.08 & 3.07 \\
\hline Cyclopentane & 5.16 & 2.24 & 0.15 \\
\hline i-Pentane & 3.90 & 1.36 & 1.72 \\
\hline n-Pentane & 3.94 & 1.22 & 1.37 \\
\hline Methylcyclopentane & 5.10 & 1.46 & 0.32 \\
\hline 2,3-Dimethylbutane & 6.30 & 1.07 & 0.13 \\
\hline 2,2-Dimethylbutane & 2.32 & 0.82 & 0.37 \\
\hline 2-Methylpentane & 5.60 & 1.40 & 0.88 \\
\hline 3-Methylpentane & 5.70 & 1.69 & 0.75 \\
\hline n-Hexane & 5.60 & 1.14 & 1.43 \\
\hline 2,4-Dimethylpentane & 5.70 & 1.11 & 0.37 \\
\hline Cyclohexane & 7.49 & 1.14 & 1.65 \\
\hline 2-Methylhexane & 6.90 & 1.09 & 0.58 \\
\hline 2,3-Dimethylpentane & 5.10 & 1.25 & 0.26 \\
\hline 3-Methylhexane & 5.10 & 1.50 & 0.52 \\
\hline 2,2,4-Trimethylpentane & 3.68 & 1.20 & 0.22 \\
\hline n-Heptane & 7.15 & 0.97 & 0.32 \\
\hline Methylcyclohexane & 10.4 & 1.56 & 0.26 \\
\hline 2,3,4-Trimethylpentane & 7.00 & 0.97 & 0.12 \\
\hline 2-Methylheptane & 8.30 & 1.12 & 0.08 \\
\hline 3-Methylheptane & 8.60 & 0.80 & 0.08 \\
\hline n-Octane & 8.68 & 0.68 & 0.19 \\
\hline $\mathrm{n}$-Nonane & 10.20 & 0.59 & 0.35 \\
\hline n-Decane & 11.60 & 0.52 & 0.03 \\
\hline n-Undecane & 13.20 & 0.47 & 0.17 \\
\hline n-Dodecane & 14.20 & 0.38 & 0.14 \\
\hline \multicolumn{4}{|l|}{ Alkenes } \\
\hline Ethene & 8.50 & 7.40 & 2.99 \\
\hline Propene & 26.30 & 11.57 & 1.32 \\
\hline trans-2-Butene & 64.00 & 15.20 & 0.28 \\
\hline 1-Butene & 31.40 & 9.57 & 0.44 \\
\hline cis-2-Butene & 56.40 & 14.26 & 0.22 \\
\hline trans-2-Pentene & 67.00 & 10.47 & 0.03 \\
\hline 1-Pentene & 31.40 & 7.07 & 0.05 \\
\hline cis-2-Pentene & 65.00 & 10.28 & 0.19 \\
\hline Isoprene & 101.00 & 10.48 & 1.14 \\
\hline 1-Hexene & - & - & 0.67 \\
\hline \multicolumn{4}{|l|}{ Alkyne } \\
\hline Ethyne & 0.9 & 0.5 & 3.90 \\
\hline
\end{tabular}


Table 2. Cont.

\begin{tabular}{cccc}
\hline Compound & $\mathbf{k}^{\mathbf{a}} \mathbf{O H} \times \mathbf{1 0}^{\mathbf{1 2}}$ & $\mathbf{M I R}^{\mathbf{b}}$ & Mixing Ratio (ppbv) (Parts Per Billion by Volume) \\
\hline Aromatics & & & \\
\hline Benzene & 1.23 & 0.42 & 1.09 \\
Toluene & 5.96 & 3.93 & 4.59 \\
Ethylbenzene & 6.96 & 2.96 & 1.48 \\
m,p-Xylene & 20.50 & 8.54 & 1.41 \\
Styrene & 58.00 & 1.66 & 0.41 \\
o-Xylene & 13.60 & 7.58 & 0.66 \\
i-Propylbenzene & 6.60 & 2.45 & 0.10 \\
n-Propylbenzene & 5.70 & 1.96 & 0.23 \\
m-Ethyltoluene & 18.60 & 7.39 & 0.25 \\
p-Ethyltoluene & 11.80 & 4.39 & 0.21 \\
1,3,5-Trimethylbenzene & 56.70 & 11.75 & 0.21 \\
o-Ethyltoluene & 11.90 & 5.54 & 0.27 \\
1,2,4-Trimethylbenzene & 32.50 & 8.83 & 0.21 \\
1,2,3-Trimethylbenzene & 32.70 & 11.94 & 0.15 \\
m-Diethylbenzene & 15.00 & 7.08 & 0.12 \\
p-Diethylbenzene & 10.00 & 4.39 & 0.11 \\
\hline
\end{tabular}

Note: ${ }^{a}$ MIR denotes maximum incremental reactivity [11]; ${ }^{b} k_{\mathrm{OH}}$ denotes rate constant of NMHCs react with hydroxyl radicals at 298K [25].

\subsubsection{Assessment of Biogenic and Anthropogenic Effects on Isoprene}

Isoprene has both biogenic and anthropogenic sources [14,15]. Some previous studies that quantified isoprene in vehicle exhaust emissions periods revealed a strong correlation between isoprene and common vehicle exhaust tracers (e.g., 1,3-butadiene and carbon monoxide) in cold seasons $[15,16,26]$. The results indicated that anthropogenic sources of isoprene are mainly a result of vehicle exhaust emissions, although some studies $[27,28]$ found human exhalation to be another anthropogenic source of isoprene. Thus, characteristic mixing ratios of isoprene and vehicle exhaust tracers can be used to assess the biogenic and anthropogenic effects on isoprene [15]. Cis-2-butene, which was identified by simple regression analyses of the mixing ratios of isoprene and vehicle exhaust tracers and determined to have a $p$-value of 0.05 from a t-test, was chosen as a tracer for anthropogenic isoprene. The average ratio between the measured isoprene and cis-2-butene mixing ratio at the GPACS in the night-time during winter (when the biogenic emission is negligible) was treated as the characteristic ratio between anthropogenic isoprene and cis-2-butene. Using the ratio calculated for the winter to assess the biogenic and anthropogenic contribution of isoprene in other seasons, the total isoprene was separated as follows:

$$
\begin{gathered}
\text { [isoprene }]_{\text {anthropogenic }}=x[\text { cis-2-butene }] \\
{[\text { isoprene }]_{\text {biogenic }}=[\text { isoprene }]_{\text {total }}-[\text { isoprene }]_{\text {anthropogenic }}}
\end{gathered}
$$

where [isoprene] $]_{\text {anthropogenic }}$ is the mixing ratio of anthropogenic isoprene, $x$ is the characteristic ratio between cis-butene and isoprene calculated for the winter months, [cis-2-butene] is the mixing ratio of cis-2-butene, [isoprene $]_{\text {biogenic }}$ is the mixing ratio of biogenic isoprene, and [isoprene] $]_{\text {total }}$ is the mixing ratio of total isoprene.

\section{Results and Discussion}

\subsection{Overall Characteristics of NMHCs and Their Relative Potential to $\mathrm{O}_{3}$ Formation}

Of the 56 measured NMHCs, three categories were identified at GPACS (Guangzhou Panyu Atmospheric Composition Station) from June 2011 to May 2012: alkanes (29 species), alkenes and alkynes (11 species), and aromatics (16 species). Figure 2 shows the day- and night-time average mixing ratios. Among these species, $\mathrm{C}_{2}-\mathrm{C}_{4}$ alkanes, ethene, acetylene, and toluene, which originated 
exclusively from anthropogenic sources, were the most abundant species. $C_{2}-C_{4}$ alkanes were mainly emitted from the leakage of liquefied petroleum gases (LPG), natural gas (NG), and gasoline evaporation; ethene and ethyne resulted from incomplete combustion, particularly vehicle exhaust emissions; and toluene was generated from biomass and biofuel burning and diesel vehicular emissions $[29,30]$. The mixing ratios of most NMHCs were slightly higher during the night-time as compared with daytime levels, except for isoprene, which indicates that isoprene had larger daytime emissions (i.e., biogenic sources), as discussed in the next section.

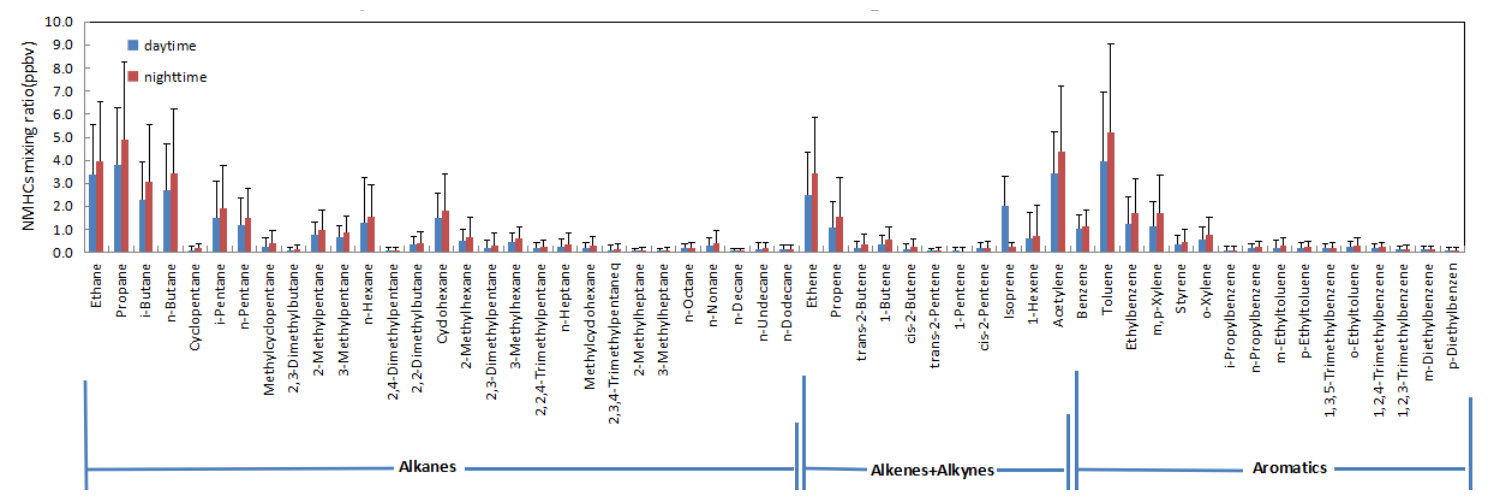

Figure 2. Average day- (7:00-18:00 LT) and night-time (19:00-6:00 LT) average mixing ratios of 56 NMHCs at GPACS (unit: ppbv). Error bars represent standard deviations from June 2011 to May 2012.

Table 3 shows the isoprene ambient mixing ratios measured at different locations in temperate and subtropical zones. The daily average mixing ratios of isoprene in spring, summer, autumn, and winter were $0.4,2.2,1.4$, and $0.13 \mathrm{ppbv}$, respectively. In contrast, the isoprene mixing ratios in subtropical cities were much higher than those in temperate zones (e.g., Beijing and London) because of the higher temperatures and higher levels of solar radiation. The values at GPACS in Guangzhou were even higher than the levels of isoprene in other subtropical cities (e.g., Taiwan and Houston), implying that isoprene may play a more important role in photochemistry in Guangzhou than in many other cities around the world. In order to further assess the importance of isoprene at GPACS, the MIR and $\mathrm{OH}$-reactivity scales (e.g., propylene-equivalent mixing ratio) were used to quickly and conveniently evaluate the $\mathrm{O}_{3}$ formation potential (OFP) or their relative reactivity during photochemical pollution formation. Figure 3 shows the annual mean relative OFP and propylene-equivalent mixing ratios of the 56 NMHCs at GPACS during a photochemical reaction process (10:00-17:00 Local Time (LT)) from June 2011 to May 2012. With regard to the OFP of NMHCs estimated by the MIR scale, isoprene was the top-ranked species, which accounted for $20.69 \%$ of the total OFPs among the 56 NMHCs. Toluene ranked second with $14.61 \%$ of the total OFPs. Following were $\mathrm{m}, \mathrm{p}$-xylene, ethene, propene, o-xylene, and then ethylbenzene, accounting for $10.01 \%, 5.13 \%, 4.99 \%, 4.44 \%$, and $4.16 \%$, respectively. Comparing the results estimated by the MIR and $\mathrm{OH}$-reactivity scales, the 10 species with the largest OFP and propylene-equivalent mixing ratios were nearly the same, although their ranking was different. The species with the highest propylene-equivalent mixing ratio was also isoprene, indicating the significance of isoprene in the $\mathrm{O}_{3}$ formation process at GPACS. The fraction of isoprene with regard to the total propylene-equivalent mixing ratio (which was higher than the sum of the next nine species) was much larger than the fraction of isoprene in the total OFP, because the MIR value of isoprene listed in Table 2 is close to that of other reactive species, while the reaction rate constant of isoprene with $\mathrm{OH}$ radicals is much higher than that of other NMHC compounds. 
Table 3. Isoprene ambient mixing ratios measured at different locations in temperate and subtropical zones.

\begin{tabular}{|c|c|c|c|c|c|}
\hline Site & Location & Year & Season & $\begin{array}{c}\text { Mean Mixing Ratio } \\
\text { or Range (ppbv) }\end{array}$ & Reference \\
\hline $\begin{array}{c}\text { National Taiwan } \\
\text { University (Urban Site) }\end{array}$ & Taipei $\left(25^{\circ} 00^{\prime} \mathrm{N} / 121^{\circ} 34^{\prime} \mathrm{E}\right)$ & 2011 & Summer & 0.72 (daily) & [15] \\
\hline $\begin{array}{l}\text { Hualin Weather Station } \\
\text { (Rural Site) }\end{array}$ & $\begin{array}{c}\text { Northern Taiwan }\left(24^{\circ} 53^{\prime}\right. \\
\left.\text { N/121 } 34^{\prime} \mathrm{E}\right)\end{array}$ & 2011 & Summer & 0.70 (daily) & [15] \\
\hline $\begin{array}{l}\text { Kasernenhof (Urban } \\
\text { Background Site) }\end{array}$ & Zurich $\left(47^{\circ} 22^{\prime} \mathrm{N} / 8^{\circ} 31^{\prime} \mathrm{E}\right)$ & 2005 & Summer & 0.16 (daily) & [31] \\
\hline Rooftop Site (Urban Site) & Essen $\left(51^{\circ} 27^{\prime} \mathrm{N} / 7^{\circ} 00^{\prime} \mathrm{E}\right)$ & 2011 & Summer & 0.09 (daily) & {$[10]$} \\
\hline $\begin{array}{l}\text { SMEARIII (Urban } \\
\text { Background Site) }\end{array}$ & Helsinki $\left(60^{\circ} 12^{\prime} \mathrm{N} / 24^{\circ} 58^{\prime} \mathrm{E}\right)$ & 2011 & Summer & 0.11 (daily) & [32] \\
\hline Writtle College (Rural Site) & Essex $\left(51^{\circ} 44^{\prime} \mathrm{N} / 0^{\circ} 25^{\prime} \mathrm{E}\right)$ & 2003 & Summer & 0.13 (daytime) & [33] \\
\hline $\begin{array}{l}\text { Eltham (Suburban } \\
\text { Background Site) }\end{array}$ & London $\left(51^{\circ} 27^{\prime} \mathrm{N} / 0^{\circ} 03^{\prime} \mathrm{E}\right)$ & 1997-2017 & Summer & 0.13 (daily) & [34] \\
\hline $\begin{array}{l}\text { Marylebone Road } \\
\text { (Urban Site) }\end{array}$ & London $\left(51^{\circ} 27^{\prime} \mathrm{N} / 0^{\circ} 03^{\prime} \mathrm{E}\right)$ & 1997-2017 & Summer & 0.15 (daily) & [34] \\
\hline Six Sites (Rural Sites) & $\begin{array}{l}\mathrm{Xi} \text { an }\left(32^{\circ} 42^{\prime}-33^{\circ} 47^{\prime}\right. \\
\left.\mathrm{N} / 107^{\circ} 44^{\prime}-109^{\circ} 24^{\prime} \mathrm{E}\right)\end{array}$ & 2011 & Summer & $0.1-3.8$ (daytime) & [35] \\
\hline $\begin{array}{l}\text { Jianfeng Mountain } \\
\text { (Remote Site) }\end{array}$ & $\begin{array}{c}\text { HainanProvince }\left(18^{\circ} 40^{\prime} \mathrm{N},\right. \\
\left.108^{\circ} 49^{\prime} \mathrm{E}\right)\end{array}$ & 2004 & Spring & 0.55 (daily) & {$[36]$} \\
\hline $\begin{array}{l}\text { Tengchong Mountain } \\
\text { (Remote Site) }\end{array}$ & $\begin{array}{c}\text { Yunnan Province }\left(24^{\circ} 570 \mathrm{~N},\right. \\
\left.98^{\circ} 29^{\prime} \mathrm{E}\right)\end{array}$ & 2004 & Spring & 0.08 (daily) & [36] \\
\hline Lin'an Station (Rural Site) & $\begin{array}{c}\text { Zhejiang Province }\left(30^{\circ} 30^{\prime} \mathrm{N},\right. \\
\left.119^{\circ} 75^{\prime} \mathrm{E}\right)\end{array}$ & 2004 & Spring & 0.40 (daily) & [36] \\
\hline $\begin{array}{l}\text { Tengyue Town } \\
\text { (Urban Site) }\end{array}$ & $\begin{array}{c}\text { Yunnan Province }\left(25^{\circ} 01^{\prime} \mathrm{N},\right. \\
\left.98^{\circ} 30^{\prime} \mathrm{E}\right)\end{array}$ & 2004 & Spring & 0.13 (daily) & [36] \\
\hline $\begin{array}{l}\text { Peking University } \\
\text { (Urban Site) }\end{array}$ & Beijing $\left(39^{\circ} 59^{\prime} \mathrm{N} / 116^{\circ} 18^{\prime} \mathrm{E}\right)$ & 2008 & Summer & 0.45 (daily) & [26] \\
\hline $\begin{array}{c}3-4 \mathrm{~km} \text { North of } \\
\text { Downtown Houston }\end{array}$ & Houston $\left(29^{\circ} 47^{\prime} \mathrm{N} / 95^{\circ} 21^{\prime} \mathrm{W}\right)$ & 2008 & Summer & 0.63 (daily) & [37] \\
\hline GPACS (Suburban Site) & $\begin{array}{c}\text { Guangzhou }\left(23^{\circ} 00^{\prime} \mathrm{N} / 113^{\circ}\right. \\
\left.21^{\prime} \mathrm{E}\right)\end{array}$ & 2011 & Spring & 0.40 (daily) & This study \\
\hline GPACS (Suburban Site) & $\begin{array}{c}\text { Guangzhou }\left(23^{\circ} 00^{\prime} \mathrm{N} / 113^{\circ}\right. \\
\left.21^{\prime} \mathrm{E}\right)\end{array}$ & 2011 & Summer & 2.20 (daily) & This study \\
\hline GPACS (Suburban Site) & $\begin{array}{c}\text { Guangzhou }\left(23^{\circ} 00^{\prime} \mathrm{N} / 113^{\circ}\right. \\
\left.21^{\prime} \mathrm{E}\right)\end{array}$ & 2011 & Autumn & 1.40 (daily) & This study \\
\hline GPACS (Suburban Site) & $\begin{array}{c}\text { Guangzhou }\left(23^{\circ} 00^{\prime} \mathrm{N} / 113^{\circ}\right. \\
\left.21^{\prime} \mathrm{E}\right)\end{array}$ & 2011 & Winter & 0.13 (daily) & This study \\
\hline
\end{tabular}

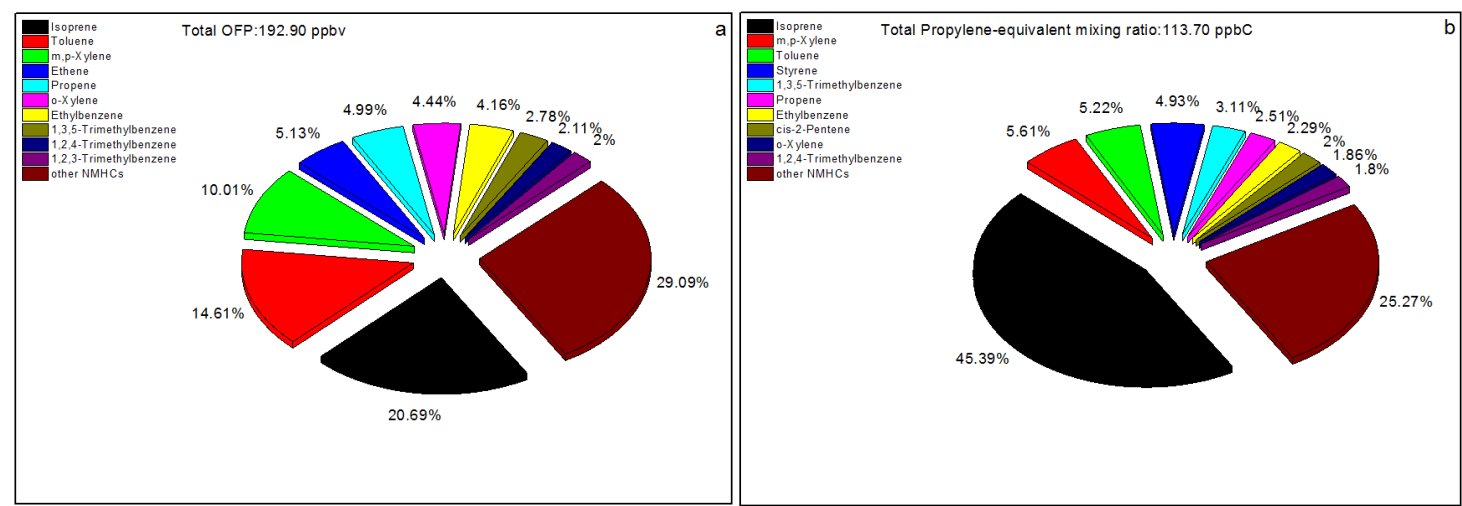

Figure 3. Fractional contribution of NMHCs to total OFP $\left(\mathrm{O}_{3}\right.$ formation potential) (a) and total propylene-equivalent mixing ratio (b) during photochemical reaction process (10:00-17:00 LT) from June 2011 to May 2012 at GPACS. 


\subsection{Biogenic and Anthropogenic Effects on Isoprene}

Diurnal variations in the mixing ratios of isoprene, temperature, and solar radiation are shown in Figure 4. The meteorological data showed a similar pattern across all seasons. The temperature varied, with regular diurnal patterns of maximum temperatures at about 15:00 LT and minimum temperatures at about 7:00 LT. The solar radiation showed unimodal variation with the peaks at approximately 12:00 LT. Ambient isoprene showed a coincident diurnal pattern of maximum mixing ratios at 13:00 LT in spring, summer, and autumn, which indicated that its biogenic emissions were closely related to temperature and solar radiation. However, in winter, isoprene was detected at low levels, and a relatively weak peak occurred at night, which indicates that the isoprene mixing ratio is correlated with anthropogenic emissions in the cold season, because its emissions from biogenic sources without illumination were negligible [38]. As previously discussed, isoprene ranked first in terms of propylene-equivalent mixing ratio and OFP, indicating the significant potential of isoprene to influence the $\mathrm{O}_{3}$ formation in Guangzhou. Further investigation of the biogenic and anthropogenic effects on isoprene is essential for $\mathrm{O}_{3}$ pollution control in Guangzhou. In this study, two common vehicular tracers (cis-2-butene and 3-methylpentane) [30] at GPACS were employed for the source apportionment of isoprene. The approach is robust at GPACS, where there are no significant industrial pollution sources nearby and the air is sufficiently homogenous with regard to various sources (e.g., vehicular emissions) near the surface of the ground [3,19-21]. Figure 5 shows the mixing ratios of isoprene versus 3-methylpentane and cis-2-butene, respectively, during the day- and night-time across the four seasons. At night-time during winter, isoprene showed a statistically significant correlation $(p<0.05)$ with cis-2-butene and 3-methylpentane (see black circles), revealing that the weak night-time peak (see Figure 4) was almost exclusively caused by vehicular emissions because isoprene has negligible emissions from biogenic sources without illumination. Compared with 3-methylpentane $\left(R^{2}=0.52\right)$, cis-2-butene exhibited a better correlation with isoprene $\left(R^{2}=0.80\right)$ in winter, because cis-2-butene and isoprene have similar chemical properties. In winter, most of the daytime data (red circles) showed a low cis-2-butene/isoprene ratio, which indicated that there were notable emissions of biogenic sources contributing to the daytime isoprene levels. In this study, the average measured cis-2-butene/isoprene ratio (0.35) at GPACS at night-time in winter was treated as the characteristic ratio between anthropogenic isoprene and cis-2-butene and was used to assess the anthropogenic and biogenic contributions to isoprene in other seasons. Figure 6 shows the estimated anthropogenic and biogenic isoprene contributions during spring, summer, and autumn at GPACS. During the daytime, it is estimated that approximately $99.2 \%, 99.5 \%$, and $97.6 \%$ of daytime isoprene was released by biogenic sources during spring, summer, and autumn, respectively. In other words, only $0.8 \%, 0.5 \%$, and $2.4 \%$ of daytime isoprene could be attributed to vehicular emissions, in spring, summer, and autumn, respectively. It should be noted that the chemical removal of NMHCs in the atmosphere is mainly dominated by the reaction with $\mathrm{OH}$ radicals [25]; therefore, the difference in the rate constants between isoprene and cis-2-butene could result in an overestimation of the vehicular contribution. However, the overestimation observed in our study results is small, since only a small fraction of the daytime isoprene level was attributed to vehicular emissions. In theory, there are negligible emissions from biogenic sources of isoprene without illumination. The reason that a fraction of biogenic isoprene existed at night is that a small amount of residual isoprene persists into the night-time after the photochemical loss during the daytime, which is also indicated by the fact that some black circles lie below the regression line at night-time during winter in Figure 5. 

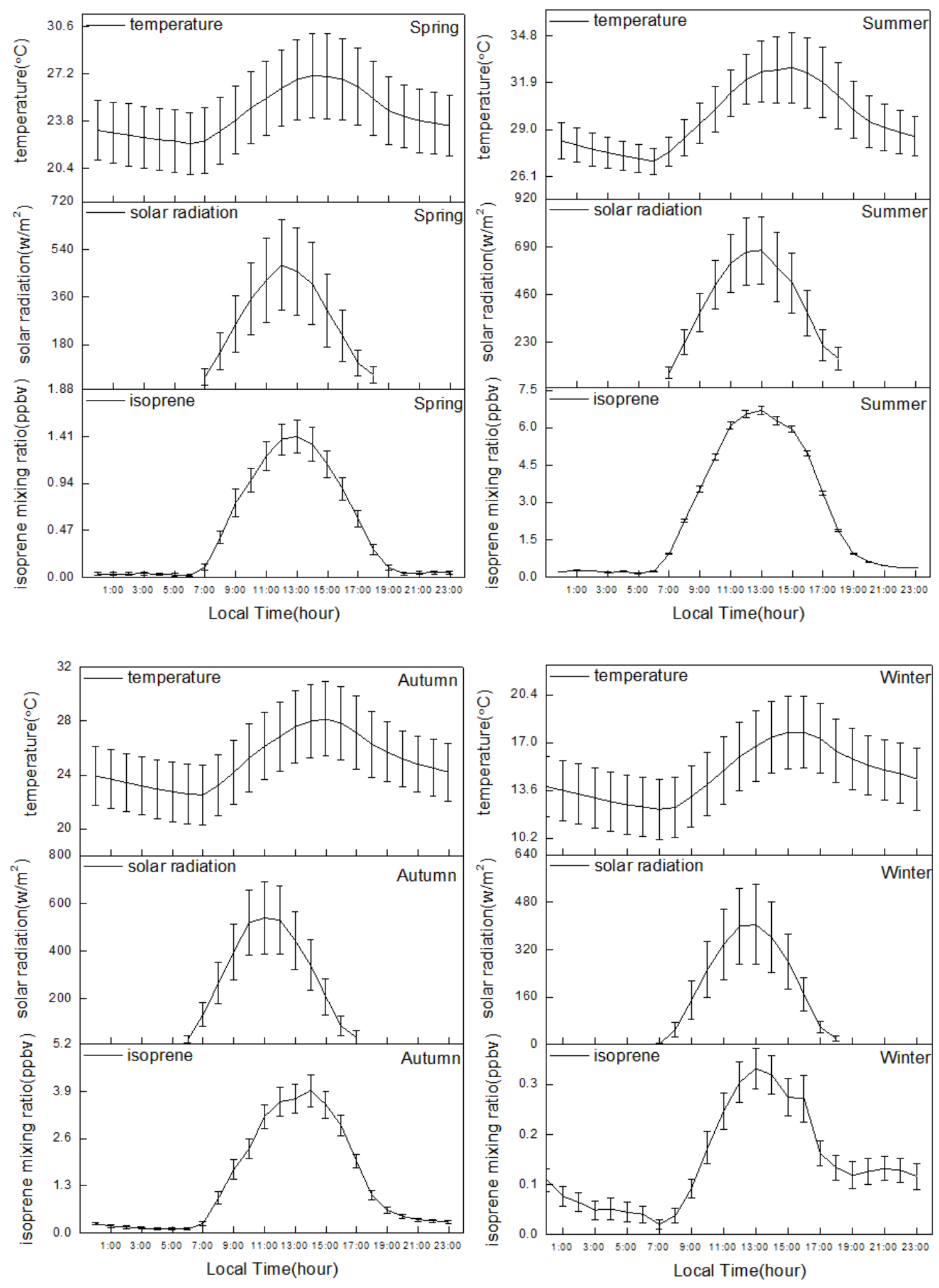

Figure 4. Diurnal variations of isoprene, solar radiation, and temperature in each season from June 2011 to May 2012 at GPACS. 

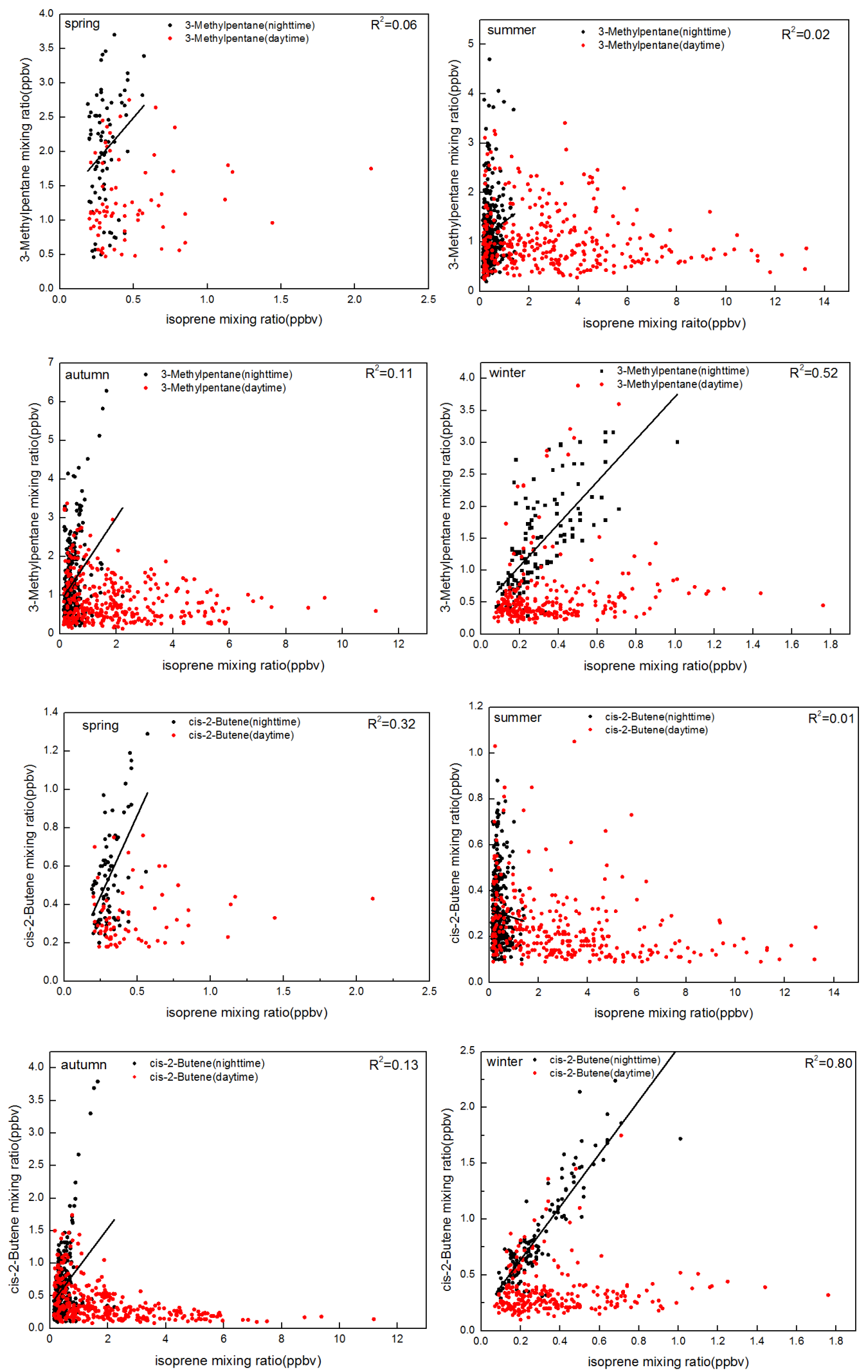

Figure 5. Mixing ratios of isoprene versus 3-methylpentane and cis-2-butene, respectively in each season from June 2011 to May 2012 at GPACS. Red circles denote the data for the daytime (7:00-18:00 LT), and black circles denote the data for the night-time (19:00-6:00 LT). Black lines represent the regression lines fit to the night-time samples (black circles). 

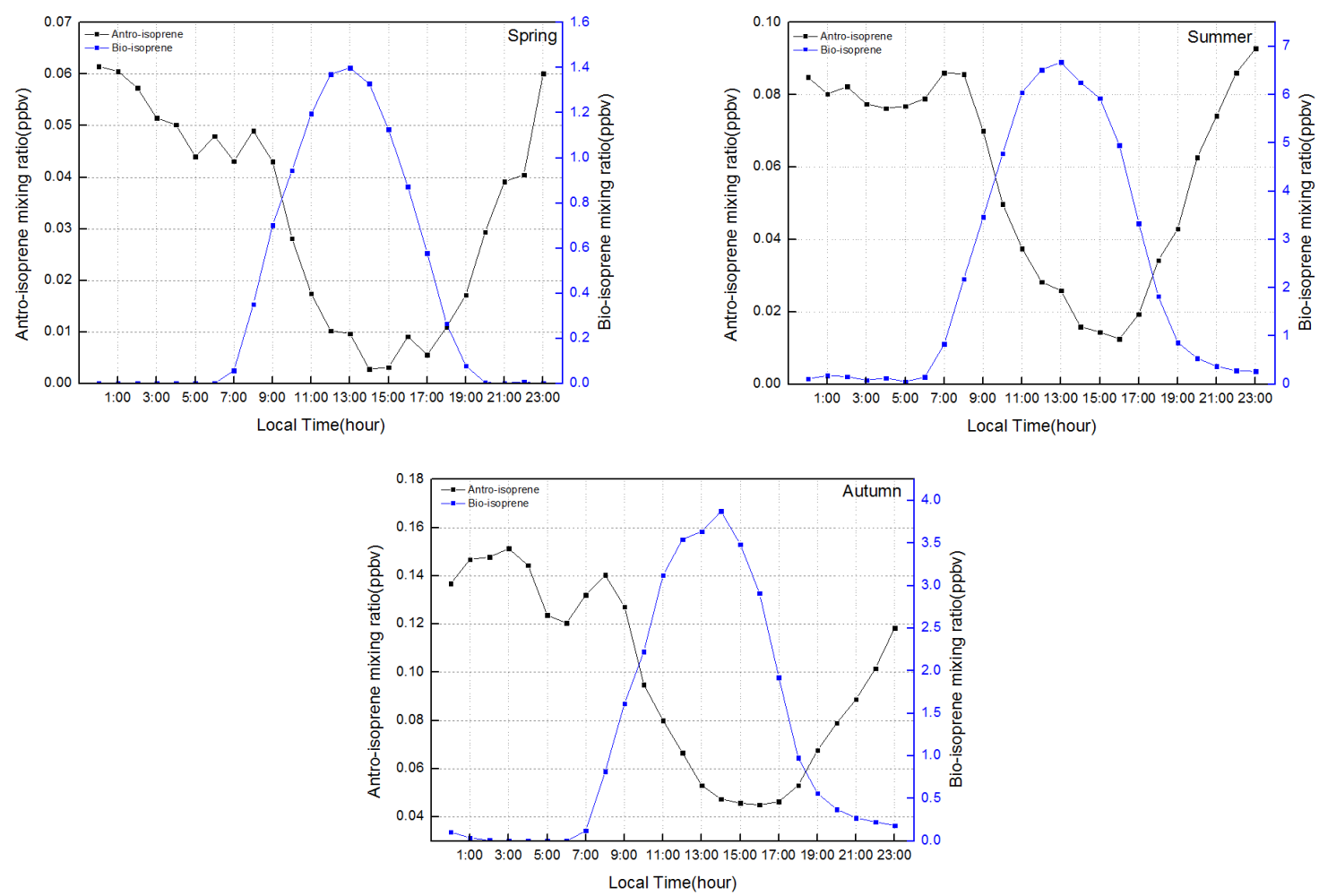

Figure 6. Diurnal patterns of the estimated anthropogenic and biogenic isoprene during spring, summer, and autumn at GPACS.

\subsection{Effect of Isoprene on Shaping the $\mathrm{O}_{3}$ Peak Profile}

Figure 7 shows the diurnal patterns of isoprene fractional contributions and four categories (alkanes, alkenes (excluding isoprene), aromatics, and ethyne) to the total mixing ratio and total photochemical reactivity (e.g., propylene-equivalent mixing ratio), respectively. Anthropogenic emissions (e.g., alkanes, alkenes, and ethyne emissions) reached their maximum values during rush hour (7:00-9:00 LT) and in the evening (19:00-23:00 LT) because most alkanes, alkenes, and alkynes consist of NMHC species related to vehicular emissions reported in PRD, such as propane, i-butane, n-butane, i-pentane, n-pentane, 3-methylpentane, ethane, propene, and ethyne [3,30,39], while the maximum isoprene emissions were observed around midday when there were high temperatures and strong solar radiation. This is because, as previously discussed, isoprene was mainly emitted from vegetation during the daytime. Although the mixing ratio of isoprene was relatively low compared to those other abundant species (i.e., $\mathrm{C}_{2}-\mathrm{C}_{4}$ alkanes, ethene, acetylene, and toluene) during the daytime, it still deserves attention because of its extremely strong photochemical reactivity. In addition, the timing of isoprene emission release is also critical from the perspective of photochemistry. The midday surge of biogenic isoprene had much more efficient production of midday $\mathrm{O}_{3}$, because this isoprene peak occurred when the most favorable meteorological conditions (e.g., high temperature and strong solar radiation) for photochemistry to occur were present, in addition to the presence of the highest $\mathrm{OH}$ mixing ratio (which could maximize photochemical reactions) [12]. As a result, isoprene could have a large effect on shaping the peak of the $\mathrm{O}_{3}$ profile (see Figure 8). The high levels of isoprene in summer and autumn could not only result in stronger $\mathrm{O}_{3}$ peaks, but could also maintain these peaks for longer, thus shaping the strong and broad $\mathrm{O}_{3}$ peak profile. In contrast, the lower mixing ratios of isoprene resulted in a weak and sharp $\mathrm{O}_{3}$ peak profile. The high-mixing ratio of $\mathrm{O}_{3}$ is particularly harmful to human health [40], as highlighted by the stringent control measures of anthropogenic pollutant emissions that have been successfully implemented in PRD, which accentuates the significance of isoprene and its great impact on air quality in Guangzhou. 

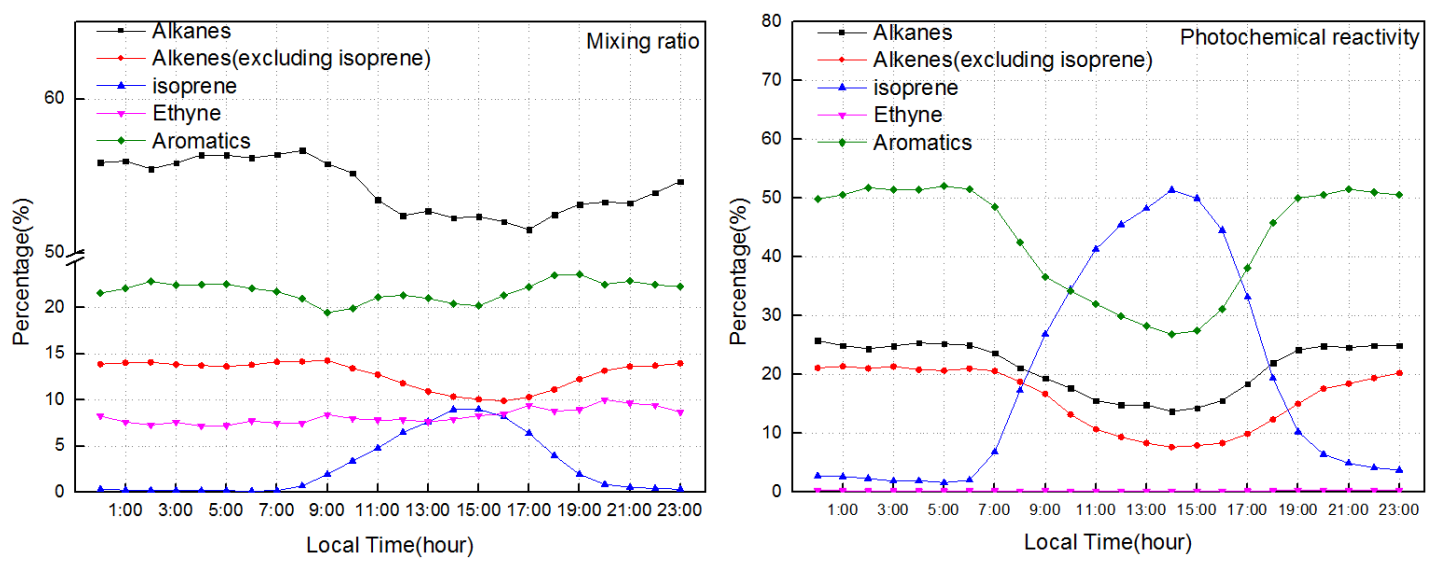

Figure 7. Diurnal variations of fractional contributions of isoprene and four categories (alkanes, alkenes (excluding isoprene), aromatics, and ethynes) to the total mixing ratio and total photochemical reactivity, respectively, from June 2011 to May 2012 at GPACS.
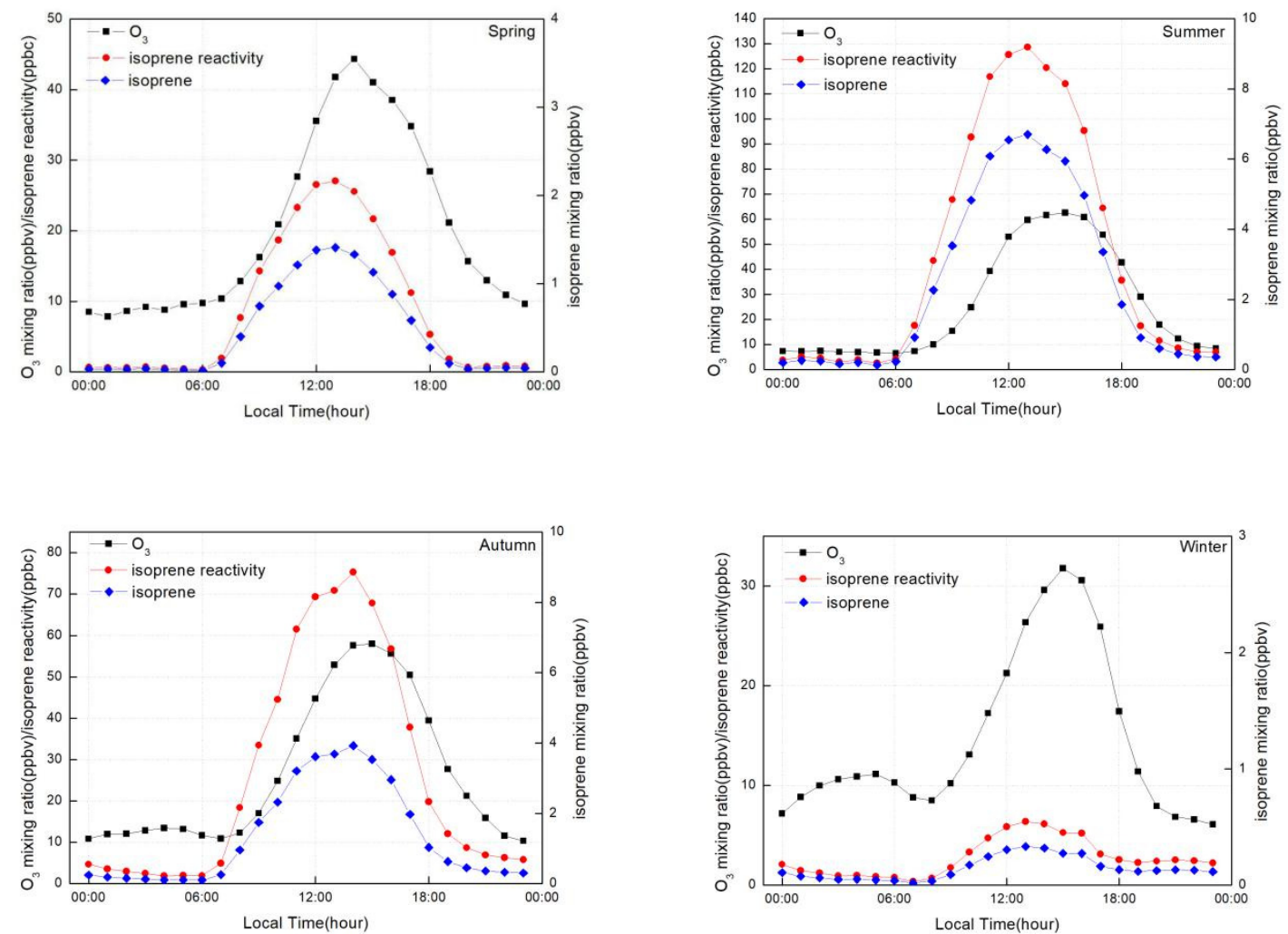

Figure 8. Diurnal variations of isoprene mixing ratios and its reactivities, as well as $\mathrm{O}_{3}$ mixing ratios in each season from June 2011 to May 2012 at GPACS.

\section{Conclusions}

Measurements of isoprene levels were conducted at Guangzhou Panyu Atmospheric Composition Station (GPACS) from June 2011 to May 2012, using the online GC-FID (gas chromatography-flame ionization detector) system to investigate the characterization and reactivity of isoprene and its effect on the $\mathrm{O}_{3}$ peak profile in different seasons. The mixing ratios of most anthropogenic NMHCs were slightly higher at night-time when compared with daytime levels at GPACS, except for isoprene, which indicates that isoprene biogenic emissions are greater in the daytime. The daily average mixing ratios of isoprene were $0.40,2.20,1.40$, and 0.13 ppbv in spring, summer, autumn, and winter, respectively, considerably higher than the mixing ratios of isoprene in most subtropical and temperate cities around the world. Isoprene ranked first in terms of $\mathrm{O}_{3}$ formation potential (OFP) and propylene-equivalent 
mixing ratio among 56 measured NMHCs during the $\mathrm{O}_{3}$ formation period, which indicates the significant potential of isoprene to influence $\mathrm{O}_{3}$ formation.

The ratios of isoprene to cis-2-butene, an exhaust tracer, were determined to estimate the fractions of biogenic and anthropogenic sources. The results revealed that the biogenic contribution was overwhelmingly greater than the anthropogenic contribution during the daytime in all four seasons. It should be noted that the difference in the rate constants between isoprene and cis-2-butene could result in an overestimation of the vehicular contribution. However, this overestimation would have been small in our study, since only a small fraction of the daytime isoprene was attributed to vehicular emissions. In addition, night-time isoprene emissions were mostly associated with vehicles in winter, which confirms that the weak night-time peak in winter was affected by vehicular emissions. The residual isoprene mixing ratio after daytime photochemical loss persisted into the night-time and also contributed to the night-time isoprene mixing ratio.

The high levels of isoprene in summer and autumn could shape the strong and broad $\mathrm{O}_{3}$ peak profiles in these seasons because of the more favorable meteorological conditions (e.g., high temperature and intense solar radiation), the higher photochemical reactivity, and the higher $\mathrm{OH}$ mixing ratio. This could affect human health by exposing people to a high $\mathrm{O}_{3}$ mixing ratio for a prolonged period, while the lower mixing ratios of isoprene resulted in a weak and sharp $\mathrm{O}_{3}$ peak profile in both spring and winter. The high level of isoprene in subtropical zones could accentuate its great impact on atmospheric oxidant capacity and air quality in Guangzhou city.

Author Contributions: This study was conceived and designed by Y.Z. and X.J.D.; The data was analyzed by Y.Z. and F.L.; The paper was written by Y.Z.; The paper was revised and improved by Y.Z., T.D. and C.Q.Y.

Funding: This study was supported by the National Key R\&D Program of China (NOs. 2018YFC0213901, 2016YFC0202003), the National Natural Science Foundation of China (NOs. 41775037, 41805131, 41605105), the Science and Technology Innovative Research Team Plan of Guangdong Meteorological Bureau (NO. 201704), and the Science and Technology Research project of Guangdong Meteorological Bureau (NO. GRMC2018M06).

Acknowledgments: The constructive suggestions from the anonymous reviewers are greatly appreciated.

Conflicts of Interest: The authors declare no conflict of interest.

\section{References}

1. Wang, T.; Wei, X.L.; Ding, A.J.; Poon, C.N.; Lam, K.S.; Li, Y.S.; Chan, L.Y.; Anson, M. Increasing surface ozone concentrations in the background atmosphere of Southern China, 1994-2007. Atmos. Chem. Phys. 2009, 9, 6217-6227. [CrossRef]

2. Zheng, J.Y.; Zhong, L.J.; Wang, T.; Louie, P.K.K.; Li, Z.C. Ground-level ozone in the Pearl River Delta region: Analysis of data from a recently established regional air quality monitoring network. Atmos. Environ. 2010, 44, 814-823. [CrossRef]

3. Zou, Y.; Charlesworth, E.; Yin, C.Q.; Yan, X.L.; Deng, X.J.; Li, F. The weekday/weekend ozone differences induced by the emissions change during summer and autumn in Guangzhou, China. Atmos. Environ. 2019, 199, 114-126. [CrossRef]

4. $\quad$ Ran, L.; Zhao, C.S.; Xu, W.Y.; Lu, X.Q.; Han, M.; Lin, W.L.; Yan, P.; Xu, X.B.; Deng, Z.Z.; Ma, N.; et al. VOC reactivity and its effect on ozone production during the HaChi summer campaign. Atmos. Chem. Phys. 2011, 11, 4657-4667. [CrossRef]

5. Zhong, L.J.; Louie, P.K.K.; Zheng, J.Y.; Yuan, Z.B.; Yue, D.L.; Ho, J.W.K.; Lau, A.K.H. Science-policy interplay: Air quality management in the Pearl River Delta region and Hong Kong. Atmos. Environ. 2013, 76, 3-10. [CrossRef]

6. Wang, N.; Lyu, X.P.; Deng, X.J.; Guo, H.; Deng, T.; Li, Y.; Yin, C.Q.; Li, F.; Wang, S.Q. Assessment of regional air quality resulting from emission control in the Pearl River Delta region, southern China. Sci. Total Environ. 2016, 573, 1554-1565. [CrossRef]

7. Li, J.F.; Lu, K.D.; Lv, W.; Li, J.; Zhong, L.J.; Ou, Y.B.; Cheng, D.H.; Huang, X.; Zhang, Y.H. Fast increasing of surface ozone concentrations in Pearl River Delta characterized by a regional air quality monitoring network during 2006-2011. J. Environ. Sci. 2014, 26, 23-26. [CrossRef] 
8. Wang, T.; Nie, W.; Gao, J.; Xue, L.K.; Gao, X.M.; Wang, X.F.; Qiu, J.; Poon, C.N.; Meinardi, S.; Blake, D.; et al. Air quality during the 2008 Beijing Olympics: Secondary pollutants and regional impact. Atmos. Chem. Phys. 2010, 10, 7603-7615. [CrossRef]

9. Chameides, W.L.; Lindsay, R.W.; Richardson, J.; Kiang, C.S. The role of biogenic hydrocarbons in urban photochemical smog: Atlanta as a case study. Science. 1988, 241, 1473-1475. [CrossRef]

10. Wagner, P.; Kuttler, W. Biogenic and anthropogenic isoprene in the near-surface urban atmosphere-Acase study in Essen, Germany. Sci. Total Environ. 2014, 475, 104-115. [CrossRef]

11. Carter, W.P.L. Development of ozone reactivity scales for volatile organic compounds. J. Air Waste Manag. Assoc. 1994, 44, 881-899. [CrossRef]

12. Lee, B.S.; Wang, J.L. Concentration variation of isoprene and its implications for peak ozone concentration. Atmos. Environ. 2006, 40, 5486-5495. [CrossRef]

13. Guenther, A.; Karl, T.; Harley, P.; Wiedinmyer, C.; Palmer, P.I.; Geron, C. Estimates of global terrestrial isoprene emissions using MEGAN (Model of Emissions of Gases and Aerosols from Nature). Atmos. Chem. Phys. 2006, 6, 3181-3210. [CrossRef]

14. Borbon, A.; Fontaine, H.; Veillerot, M.; Locoge, N.; Galloo, J.C.; Guillermo, R. An investigation into the traffic-related fraction of isoprene at an urban location. Atmos. Environ. 2001, 35, 3749-3760. [CrossRef]

15. Wang, J.L.; Chew, C.; Chang, C.Y.; Liao, W.C.; Lung, C.S.C.; Chen, W.N.; Lee, P.J.; Lin, P.H.; Chang, C.C. Biogenic isoprene in subtropical urban settings and implications for air quality. Atmos. Environ. 2013, 79, 369-379.

16. Reimann, S.; Pierluigi, C.; Hofer, P. The anthropogenic fraction contribution to isoprene concentrations in a rural atmosphere. Atmos. Environ. 2000, 34, 109-115. [CrossRef]

17. Ran, L.; Zhao, C.; Geng, F.; Tie, X.; Tang, X.; Peng, L.; Zhou, G.; Yu, Q.; Xu, J.; Guenther, A. Ozone photochemical production in urban Shanghai, China: Analysis based on ground level observations. J. Geophys. Res. 2009, 114. [CrossRef]

18. Deng, T.; Wu, D.; Deng, X.J.; Tan, H.B.; Li, F.; Liao, B.T. A vertical sounding of severe haze process in Guangzhou area. Sci. China. Earth Sci. 2014, 57, 2650-2656. [CrossRef]

19. Liu, L.; Tan, H.B.; Fan, S.J.; Cai, M.F.; Xu, H.B.; Lei, F.; Chan, P.W. Influence of aerosol hygroscopicity and mixing state on aerosol optical properties in the Pearl River Delta region, China. Sci. Total Environ. 2018, 627, 1560-1571. [CrossRef]

20. Zou, Y.; Deng, X.J.; Zhu, D.; Gong, D.C.; Wang, H.; Li, F.; Tan, H.B.; Deng, T.; Mai, B.R.; Liu, X.T.; et al. Characteristics of 1 year of observational data of VOCs, NOx and $\mathrm{O}_{3}$ at a suburban site in Guangzhou, China. Atmos. Chem. Phys. 2015, 15, 6625-6636. [CrossRef]

21. Tan, H.B.; Liu, L.; Fan, S.J.; Li, F.; Yin, Y.; Cai, M.F.; Chan, P.W. Aerosol optical properties and mixing state of black carbon in the Pearl River Delta, China. Atmos. Environ. 2016, 131, 196-208. [CrossRef]

22. Main, H.H.; Roberts, P.T.; Hurwitt, S.B. Validation of PAMS VOC Data in the Mid-Atlantic Region. Report Prepared for MARAMA, Baltimore, MD. Sonoma Technology, Inc., Petaluma, 1999, CA STI-998481-1835-FR. Available online: http://www.marama.org/publications_folder/Validation_of_PAMS_Report_feb1999.pdf (accessed on 20 October 2012).

23. An, J.L.; Zhu, B.; Wang, H.L.; Li, Y.Y.; Lin, X.; Yang, H. Characteristics and source apportionment of VOCs measured in an industrial area of Nanjing, Yangtze River Delta, China. Atmos. Environ. 2014, 97, 206-214. [CrossRef]

24. Dodge, M.C. Combined effects of organic reactivity and $\mathrm{NMHC} / \mathrm{NO}_{\mathrm{x}}$ ratio on photochemical oxidant formation-A modeling study. Atmos. Environ. 1984, 18, 1657-1665. [CrossRef]

25. Atkinson, R.; Arey, J. Atmospheric degradation of volatile organic compounds. Chem. Rev. 2003, 103, 4605-4638. [CrossRef]

26. Chang, C.C.; Shao, M.; Chou, C.C.K.; Liu, S.C.; Wang, J.L.; Lee, K.Z.; Lai, C.H.; Zhu, T.; Lin, P.H. Biogenic isoprene and implications for oxidant levels in Beijing during the 2008 Olympic Games. Atmos. Chem. Phys. Discuss. 2013, 13, 25939-25967. [CrossRef]

27. Kinoyama, M.; Nitta, H.; Watanabe, A.; Ueda, H. Acetone and isoprene concentrations in exhaled breath in healthy subjects. J. Health Sci. 2008, 54, 471-477. [CrossRef] 
28. Kushch, I.; Arendacká, B.; Štolc, S.; Mochalski, P.; Filipiak, W.; Schwarz, K.; Schwentner, L.; Schmid, A.; Dzien, A.; Lechleitner, M.; et al. Breath isoprene-aspects of normal physiology related to age, gender and cholesterol profile as determined in a proton transfer reaction mass spectrometry study. Clin. Chem. Lab. Med. 2008, 46, 1011-1018. [CrossRef]

29. Zheng, J.Y.; Shao, M.; Che, W.W.; Zhang, L.J.; Zhong, L.J.; Zhang, Y.H.; Streets, D. Speciated VOC emission inventory and spatial patterns of ozone formation potential in the Pearl River Delta, China. Environ. Sci. Technol. 2009, 43, 8580-8586. [CrossRef] [PubMed]

30. Guo, H.; Cheng, H.R.; Ling, Z.H.; Louie, P.K.K.; Ayoko, G.A. Which emission sources are responsible for the volatile organic compounds in the atmosphere of Pearl River Delta? J. Hazard. Mater. 2011, 188, 116-124. [CrossRef]

31. Legreid, G.; Lööv, J.B.; Staehelin, J.; Hüglin, C.; Hill, M.; Buchmann, B.; Prevot, A.S.H.; Reimann, S. Oxygenated Volatile Organic Compounds (OVOCs) at an urban background site in Zürich (Europe): seasonal variation and source allocation. Atmos. Environ. 2007, 41, 8409-8423. [CrossRef]

32. Hellén, H.; Tykkä, T.; Hakola, H. Importance of monoterpenes and isoprene inurban air in northern Europe. Atmos. Environ. 2012, 59, 59-66. [CrossRef]

33. Lee, J.D.; Lewis, A.C.; Monks, P.S.; Jacob, M.; Hamilton, J.F.; Hopkins, J.R.; Watson, N.M.; Saxton, J.E.; Ennis, C.; Carpenter, L.J.; et al. Ozone photochemistry and elevated isoprene during the UK heatwave of August 2003. Atmos. Environ. 2003, 40,7598-7613. [CrossRef]

34. Khan, M.A.H.; Schlich, B.L.; Jenkin, M.E.; Shallcross, B.M.A.; Moseley, M.; Waler, C.; Morris, W.C.; Derwent, R.G.; Percival, C.J.; Shallcross, D.E. A two-decade anthropogenic and biogenic isoprene emissions study in a London urban background and a London urban traffic site. Atmosphere 2018, 9, 387. [CrossRef]

35. Li, N.; He, Q.Y.; Greenberg, J.; Guenther, A.; Li, J.Y.; Cao, J.J.; Wang, J.; Liao, H.; Wang, Q.Y.; Zhang, Q. Impacts of biogenic and anthropogenic emissions on summertime ozone formation in the Guangzhou Basin, China. Atmos. Chem. Phys. 2018, 18, 7489-7507. [CrossRef]

36. Tang, J.H.; Chan, L.Y.; Chang, C.C.; Liu, S.; Li, Y.S. Characteristics and sources of non-methane hydrocar-bons in background atmospheres of eastern, southwestern, and southern China. J. Geophys. Res.-Atmos. 2009, 114, D03304. [CrossRef]

37. Park, C.; Schade, G.; Boedeker, I. Characteristics of the flux of isoprene and its oxidation products in an urban area. J. Geophys. Res. 2011, 116, D21303. [CrossRef]

38. Shao, M.; Czapiewski, K.V.; Heiden, A.C.; Kobel, K.; Komenda, M.; Koppmann, R.; Wildt, J. Volatile organic compound emissions from Scots pine: Mechanisms and description by algorithms. J. Geophys. Res. 2001, 106, 20483-20491. [CrossRef]

39. Ling, Z.H.; Guo, H.; Cheng, H.R.; Yu, Y.F. Sources of ambient volatile organic compounds and their contributions to photochemical ozone formation at a site in the Pearl River Delta, southern China. Environ. Pollut. 2011, 159, 2310-2319. [CrossRef]

40. Castellanos, P.; Stehr, J.W.; Dickerson, R.R.; Ehrman, S.H. The sensitivity of modeled ozone to the temporal distribution of point, area, and mobile source emissions in the eastern United States. Atmos. Environ. 2009, 43, 4603-4611. [CrossRef]

(C) 2019 by the authors. Licensee MDPI, Basel, Switzerland. This article is an open access article distributed under the terms and conditions of the Creative Commons Attribution (CC BY) license (http://creativecommons.org/licenses/by/4.0/). 